\title{
Enhancing Quality of Drying Mixed Shrimp Paste from Karawang with Red Pigment by Angkak
}

\author{
Dessy Agustina Sari ${ }^{1}$, Muhamad Djaeni ${ }^{1}$, Azafilmi Hakiim $^{2}$, Sukanta $^{2}$, Nurul Asiah $^{3}$, Didik Supriyadi $^{4}$
}

\begin{abstract}
Ciparage beach, Karawang - West Java. Perpetrators produced 2 products such as shrimp paste and mixed shrimp paste. Utilization of Rebon shrimp by totality does not need other additives because drying process brings out the color that had itself so final product becomes redness. Involvement of Petek fish almost partially could reduce the color quality so the society used Rhodamine-B dye. This is widely spreading in the area because this matter is distributed by seller directly door to door and the price is affordable - cheaper. Novelty this research is application of tray dryer with operating temperature variables $-40,50,60^{\circ} \mathrm{C}$ for 7 hours and the presence of Angkak as natural the red pigment that it is safe for human health. The results showed that the optimum condition of drying mixed shrimp paste was achieved by temperature $40^{\circ} \mathrm{C}$. This is not about how much and quickly the moisture that evaporating into the air. Paradigm to chemical composition - organoleptic and antioxidant activity - DPPH method also was be consideration for that matter. Physically, this dried product had normal smell, salty taste, brown color, soft texture, solid shape, and normal appearance.
\end{abstract}

Keywords_-antioxidant activity, chemical composition, agent dye, Rhodamine-B, temperature, tray dryer.

\section{INTRODUCTION}

$\mathrm{K}$ arawang had some TPI fish auctions such as Ciparage, Cilamaya - West Java. Near of the location, partly society utilized this area as farmer of shrimp paste. Conventional technic and equipment were used for the production activity. After that, the product without label was sold to Karawang, Indramayu, and Cirebon traditional market with additional process. Furthermore, shrimp paste was implemented as sources for fatty acid for human body [1].

Color and odor became physical - chemical indicator that material of product was made from shrimp. Indonesia people called shrimp paste ("terasi udang"). Mostly, Rebon shrimp was main substance that gotten from the TPI. In this case, the subject did 2 ardors originality ("UU") and blend. The second object ("UI") became focus this research that it was mixed matter between fish ("Petek" - kind of fish) and shrimp. This alternative was caused the fish was not consumed small size and be abundant in Ciparage.

All this time, improvement appearance of the yield was manipulated by adding dye, Rhodamine B ("R") because it had cheaper price and little employing. However, this stuff was banned from Department of Health - see Figure 1. Angkak ("A") was natural agent color that could be option for food additives such as chicken sausage [2]. This material was safe for consumption with the lowering the blood cholesterol property [3]. The red

${ }^{1}$ Dessy Agustina Sari and Muhamad Djaeni are with Department of Electrical Engineering, University of Singaperbangsa Karawang, Karawang - West Java, 41361, Indonesia. E-mail: dessy.agustina8@staff.unsika.ac.id

${ }^{2}$ Azafilmi Hakiim and Sukanta are with Department of Industrial Engineering, University of Singaperbangsa Karawang, Karawang West Java, 41361, Indonesia.

${ }^{3}$ Nurul Asiah is with Department of Food Technology, Bakrie University, South Jakarta - DKI Jakarta, 12940, Indonesia.

${ }^{4}$ Didik Supriyadi is with Department of Chemical Engineering, Institution of Technology Sumatera, South Lampung - Lampung, 35365, Indonesia. pigment that owned was protector as long drying process to watch over chemical composition and antioxidant activity. Variation of temperature as operating condition was from 40 until $60^{\circ} \mathrm{C}$ for 7 hours.

\section{METHOD}

The research utilized Petek fish (see Figure 2), Rebon shrimp, sugar, dye (Rhodamine-B and Angkak), and coarse salt. The procedure was explained step by step this below:

\section{A. Preliminary Matter}

Rebon shrimp which obtained mingled impurities. Separation by hand and specific gravity were applied to get better matter. After that, immersion with using salted water was used to eliminate formalin and reduce salty levels for 1 hour. Comparison for ingredient and water was $1: 2$ with salt that given was $2,5 \%$ from distilled water [4]. As many 5-7 times, washing was did to make sure cleaning. This way was also for "Petek". Result from [5] showed that low salt fermented had a high acidifying activities and were capable reduce the $\mathrm{pH}$ lower than 4,5 .

\section{B. Drying Product}

Drying process was occurred in tray dryer with 3 stages for 6 days. The $1^{\text {st }}$ and $2^{\text {nd }}$ days: shrimp and fish were separately dried in each 3,5hours respectively then let stand until tomorrow (fermentation process). Third and fourth days: both of components had mixed into porridge (milling and blending process). This phase affixed sugar, powder dye, and salt. Subsequently, researcher used circle shape for printing semi product with $38 \mathrm{~g}$ as net weight.

\section{Composition Product}

Test of dried shrimp paste was physical - chemical composition and antioxidant activity by organoleptic and DPPH method successively.

\section{RESULT AND DISCUSSION}

Beforehand, farmer Ciparage utilized sunshine (SM) to dry seafood in our yard which bordered the animal 
cage. Insects - other animals and environmental condition disturbed the quality dried product. Tray dryer as modern drying was applied to overcome it [6], [7] and capable presented a hygiene shrimp paste - extended shelf life [8]. Rhodamine-B was synthetic dye that used
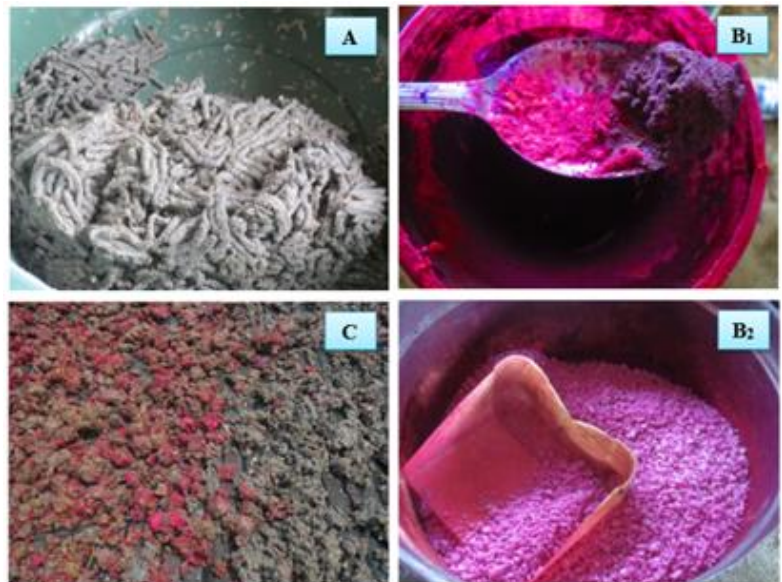

Figure 1. Paste of Petek fish and Rebon shrimp: (A) before added dye; $\left(\mathrm{B}_{1}\right)$ powder Rhodamine-B;

$\left(\mathrm{B}_{2}\right)$ mixed salt and synthetic matter $-1 \mathrm{~kg}$ salt: $4 \mathrm{~g}$ dye; $(\mathrm{C})$ the paste with and without the color.

Result this research was provided Figure 3 and 4 that showing declination of moisture content from the substance with constant velocity air for 7 hours. Table 1 served the result of dried shrimp paste that caused the heated air. Comparison the matter was also done between UI and UU to other dyes.

In Figure 1, temperature $40^{\circ} \mathrm{C}$ was optimum condition for drying shrimp paste and gave a significant effect in moisture content from other variables. The result research showed that using Angkak preferred in lower temperature to more release the water to the air. This was judgement also based on Table 1. The mass loss was not only caused the evaporating water, but other composition that had sample under the drying condition. This was same statement by researcher of fish paste [9]. Nevertheless, the SM was significant and even UI50A, but the fluctuation of day could not be predicted exactly. This was the disadvantage. Furthermore, drying process just could be done in quiet light, from 10 am until 2 pm with specially month - the weather and the researchers made many barriers to handle the animal as long the drying in our grounds.

Rhodamine-B, Angkak, and no dye ("Nol") of sample already had done in laboratory on drying of blended Rebon shrimp and Petek fish (1:1). Then, comparison between synthetic pigments to Angkak was 1:20 that stirred first with salt. This was easy way to combine the both. The powder dye was more easily mixed with coarse salt than the fine. Afterwards, in same temperature by Figure 2, condition without agent color presented the decreasing moisture faster than others. This thing indicated that it tied water not to evaporate.

Based on Table 1, lower temperature in tray dryer with using Angkak caused percentage of antioxidant activity more increased and advanced this condition reduced the value. Researchers [10] stated that temperature process gave more significant impact on color than time. Then, pigment and lovastatin production of Angkak was influenced by $\mathrm{pH}$, temperature, moisture, nutrients and fungal strain [11]. Decline of color intensity of puree was mostly in milling process. The color remained in this device for long time and pierce. This was difficult to be cleaned until now. So, it added thick sample if the equipment was used over and over.

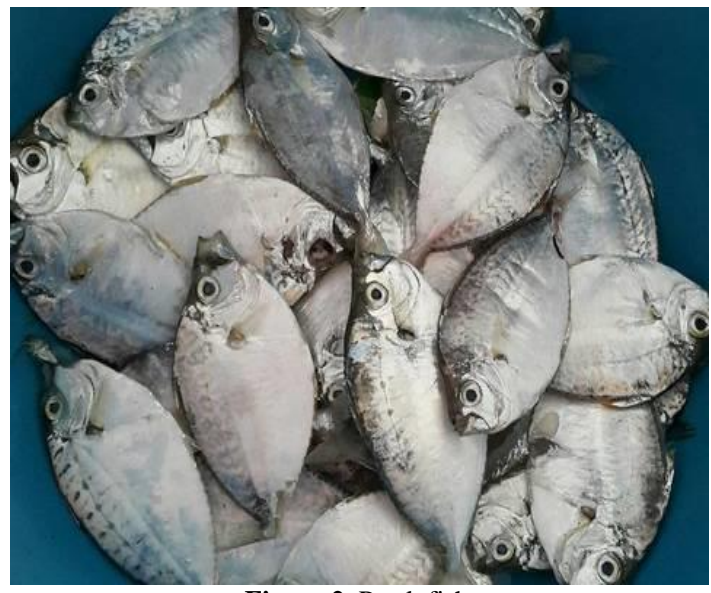

Figure 2. Petek fish.

(https://cookpad.com/id/resep/945576-homemade-ikan-asin).

due to degradation of responsible pigments. Thereupon, fermentation also had a role. Researchers [9] declared that this process improved antioxidant activity, $\mathrm{pH}$, and water content. Fermented food was ancient technic to enhance the functional and variate flavor value of the matter [12]. Angkak was made from the process. This statement reinforced the result in Table 1 . The fermentation took place after 3,5 hours the drying and it was being held every day for 6 days. So, degradation the product was generated during fermentation and this result also supported by [13].

Then, the red pigment also could replace the role of Rhodamine-B as a color agent. This thing was proofed through the score of inhibition in same condition that temperature $40^{\circ} \mathrm{C}$ was higher than synthetic matter. The standardization of moisture was more than $35 \%$. Other side, research of Belacan - Bruneian shrimp paste played freeze drying method for 15 hours. The result showed that the product had higher moisture and protein $(47,92$ and $30,38 \%$, respectively) than the Karawang yield. For the fat and ash content contrasted before such as 0,63 and $24,02 \%$ in succession [14].

Sample ("UU" - all of the Rebon shrimp) did not attach any dye. Showing itself before and after the drying was still redness. The protein in $40^{\circ} \mathrm{C}$ was higher in same matter and different temperature than UU50 and SMUU. The Rebon was good sources of nutrients as well as natural antioxidants. This also was founded on result of Klongkone shrimp paste [15].

Implementation Angkak was just applied for the mixed material, while other product - originality did not need it. The Rebon shrimp issued red color if it was exposed heat (the air that sucked by blower heated - hot air). Whereas, adding Petek fish would relieve the color that had itself. Other hand, the researchers guessed that existence of Petek fish contributed flavor and taste the mixed shrimp paste. This argument also stated by [16] that high glutamic acid was conceived fish paste and affected the both indicators. Moreover, salt would enhance both the shelf life and flavor for Thai traditional shrimp paste [13]. Other that, this research through 
physical test, the product had normal odor, salty taste, brown color, soft texture, solid shape, and normal appearance. This was all of the sample except SMUI that looked at drier than others, see Figure 7 in the result [4].

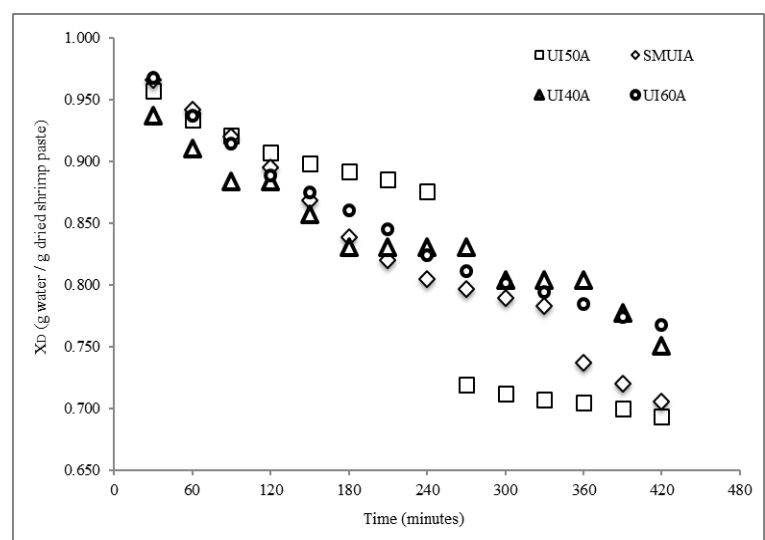

Figure 3. Effect of temperature to moisture content of dried shrimp paste.
Sample ("UU" - all of the Rebon shrimp) did not attach any dye. Showing itself before and after the drying was still redness. The protein in $40^{\circ} \mathrm{C}$ was higher in same matter and different temperature than UU50 and SMUU.

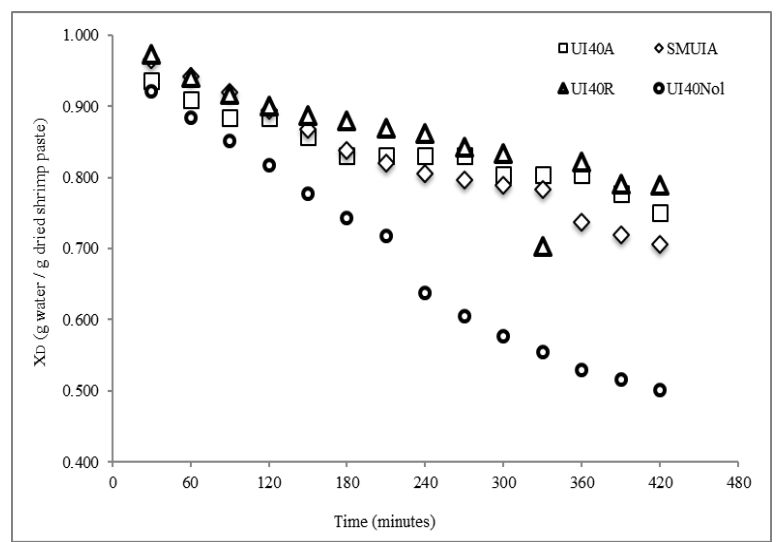

Figure 4. Effect of type dye to moisture content of dried shrimp paste.

TABLE 1.

CHEMICAL COMPOSITION AND ANTIOXIDANT ACTIVITY

\begin{tabular}{|c|c|c|c|c|c|c|c|c|c|}
\hline \multirow[b]{2}{*}{ Condition } & \multicolumn{7}{|c|}{ "Organoleptic } & \multicolumn{2}{|c|}{ \% Inhibition } \\
\hline & $\begin{array}{c}\text { Total } \\
\text { carbohydrate, } \\
\%\end{array}$ & $\begin{array}{c}\text { Total fat, } \\
\%\end{array}$ & $\begin{array}{c}\text { Energy } \\
\text { from fat, } \\
\mathrm{kcal} / 100 \mathrm{~g}\end{array}$ & $\begin{array}{c}\text { Total } \\
\text { energy, } \\
\text { kcal } / 100 \mathrm{~g}\end{array}$ & $\begin{array}{c}\text { Protein, } \\
\%\end{array}$ & $\begin{array}{c}\text { Moisture, } \\
\%\end{array}$ & $\begin{array}{c}\text { Ash } \\
\text { content, } \\
\%\end{array}$ & Test 1 & Test 2 \\
\hline UI40Nol & 12,83 & 2,44 & 21,96 & 135,00 & 15,43 & 43,84 & 24,46 & 82,75 & 84,40 \\
\hline UI40R & 6,24 & 3,26 & 29,34 & 171,66 & 29,34 & 34,94 & 26,22 & 78,71 & 78,00 \\
\hline UI40A & 9,94 & 3,06 & 27,54 & 176,74 & 27,36 & 35,62 & 24,02 & 79,79 & 79,79 \\
\hline UI50Nol & 0,14 & 2,54 & 22,86 & 123,90 & 25,12 & 46,38 & 25,82 & 75,05 & 75,23 \\
\hline UI50A & 5,38 & 1,84 & 16,56 & 126,24 & 22,04 & 44,92 & 25,82 & 78,35 & 78,17 \\
\hline UI60A & 20,62 & 2,60 & 23,40 & 192,40 & 21,63 & 29,17 & 25,98 & 75,78 & 77,06 \\
\hline SMUIR & 10,37 & 3,08 & 27,72 & 145,96 & 19,19 & 44,30 & 23,06 & 68,44 & 72,48 \\
\hline SMUU & 12,24 & 2,47 & 22,23 & 162,51 & 22,83 & 38,48 & 23,98 & 60,18 & 60,55 \\
\hline UU40 & 0,75 & 2,05 & 18,45 & 123,45 & 25,50 & 48,51 & 23,19 & 80,86 & 80,32 \\
\hline UU50 & 18,85 & 2,60 & 23,40 & 178,28 & 19,87 & 31,54 & 27,14 & 76,33 & 77,61 \\
\hline
\end{tabular}

Based on Table 1, lower temperature in tray dryer with using Angkak caused percentage of antioxidant activity more increased and advanced this condition reduced the value. Researchers [10] stated that temperature process gave more significant impact on color than time. Then, pigment and lovastatin production of Angkak was influenced by $\mathrm{pH}$, temperature, moisture, nutrients and fungal strain [11]. Decline of color intensity of puree was due to degradation of responsible pigments. Thereupon, fermentation also had a role. Researchers [9] declared that this process improved antioxidant activity, $\mathrm{pH}$, and water content. Fermented food was ancient technic to enhance the functional and variate flavor value of the matter [12]. Angkak was made from the process. This statement reinforced the result in Table 1. The fermentation took place after 3,5 hour the drying and it was be held every day for 6 days. So, degradation the product was generated during fermentation and this result also supported by [13].

Then, the red pigment also could replace the role of Rhodamine-B as a color agent. This thing was proofed through the score of inhibition in same condition that temperature $40^{\circ} \mathrm{C}$ was higher than synthetic matter. The standardization of moisture was more than $35 \%$. Other side, research of Belacan - Bruneian shrimp paste played freeze drying method for 15 hours. The result showed that the product had higher moisture and protein $(47,92$ and $30,38 \%$, respectively) than the Karawang yield. For the fat and ash content contrasted before such as 0,63 and $24,02 \%$ in succession [14].
The Rebon was good sources of nutrients as well as natural antioxidants. This also was founded on result of Klongkone shrimp paste [15].

Implementation Angkak was just applied for the mixed material, while other product - originality did not need it. The Rebon shrimp issued red color if it was exposed heat (the air that sucked by blower heated - hot air). Whereas, adding Petek fish would relieve the color that had itself. Other hand, the researchers guessed that existence of Petek fish contributed flavor and taste the mixed shrimp paste. This argument also stated by [16] that high glutamic acid was conceived fish paste and affected the both indicators. Moreover, salt would enhance both the shelf life and flavor for Thai traditional shrimp paste [13]. Other that, this research through physical test, the product had normal odor, salty taste, brown color, soft texture, solid shape, and normal appearance. This was all of the sample except SMUI that looked at drier than others, see Figure 7 in the result [4].

\section{CONCLUSION}

Tray dryer was one of modern equipment for drying process without it depend the day condition. Product of dried shrimp paste had unique odor that liked insects so this apparatus could hold evaporating water in closed room - dryer chamber to keep hygienic matters. Release water in sample with increasing temperature caused derivation of chemical composition and antioxidant activity. Existence of Angkak was suitable for the lower form. 


\section{ACKNOWLEDGEMENTS}

This research was funded by DIKTI grant - Penelitian Dosen Pemula in 2018.

\section{REFERENCES}

[1] R. Khairina, Y. Fitrial, H. Satrio, and N. Rahmi, 'Physical, Chemical, and Microbiological Properties of "Ronto" a Traditional Fermented Shrimp from South Borneo, Indonesia', Aquat. Procedia, vol. 7, pp. 214-220, Aug. 2016.

[2] H. Lukman, 'Alternatif Angkak Sebagai Bahan Tambahan Pangan Alami Terhadap Karakteristik Sosis Daging Ayam', J. Ilm. Ilmu-Ilmu Peternak., vol. 18, no. 2, pp. 51-57, 2015.

[3] P. Pattanagul, R. Pinthong, A. Phianmongkhol, and N. Leksawasdi, 'Review of angkak production (Monascus purpureus)', Chiang Mai J Sci, vol. 34, no. 3, pp. 319-328, 2007.

[4] D. A. Sari, Sukanta, and A. Hakiim, 'PENGERINGAN TERASI LOKAL KARAWANG: SINAR MATAHARI-TRAY DRYER', JST J. Sains Dan Teknol., vol. 6, no. 2, pp. 311-320, 2017.

[5] X. Zeng et al., 'Technological properties of Lactobacillus plantarum strains isolated from Chinese traditional low salt fermented whole fish', Food Control, vol. 40, pp. 351-358, 2014.

[6] M. Djaeni and D. A. Sari, 'Low Temperature Seaweed Drying Using Dehumidified Air', Procedia Environ. Sci., vol. 23, pp. 210, 2015.

[7] M. Djaeni, D. Anggoro, G. W. Santoso, D. Agustina, N. Asiah, and C. L. Hii, 'Enhancing The Food Product Drying with Air Dehumidified by Zeolite', Adv. J. Food Sci. Technol., vol. 6, no. 7, pp. 833-838, Jul. 2014.
[8] D. Sari and Hadiyanto, 'Teknologi dan Metode Penyimpanan Makanan sebagai Upaya Memperpanjang Shelf Life', J. Apl. Teknol. Pangan, vol. 2, no. 2, pp. 52-59, 2013.

[9] A. D. Anggo, W. F. Ma'ruf, F. Swastawati, and L. Rianingsih, 'Changes of Amino and Fatty Acids in Anchovy (Stolephorus Sp) Fermented Fish Paste with Different Fermentation Periods', Procedia Environ. Sci., vol. 23, pp. 58-63, 2015.

[10] B. Sobhi, M. Noranizan, S. A. Karim, R. A. Rahman, J. Bakar, and Z. Ghazali, 'Microbial and quality attributes of thermally processed chili shrimp paste.', Int. Food Res. J., vol. 19, no. 4, 2012.

[11] H. DANURI, 'Optimizing angkak pigments and lovastatin production by Monascus purpureus', HAYATI J. Biosci., vol. 15, no. 2, pp. 61-66, 2008.

[12] R. Kawuri, 'Red Mold Rice (Angkak) sebagai Makanan Terfermentasi dari China: Suatu Kajian Pustaka', J. Biol., vol. 17, no. 1, 2013.

[13] R. Daroonpunt, M. Uchino, Y. Tsujii, M. Kazami, D. Oka, and S. Tanasupawat, 'Chemical and physical properties of Thai traditional shrimp paste (Ka-pi)', J. Appl. Pharm. Sci., pp. 058062, 2016.

[14] Y.-B. Kim, Y.-S. Choi, S.-K. Ku, D.-J. Jang, H. H. bint Ibrahim, and K. B. Moon, 'Comparison of quality characteristics between belacan from Brunei Darussalam and Korean shrimp paste', J. Ethn. Foods, vol. 1, no. 1, pp. 19-23, Dec. 2014.

[15] N. Prapasuwannakul and K. Suwannahong, 'Chemical Composition and Antioxidant Activity of Klongkone Shrimp Paste', Procedia - Soc. Behav. Sci., vol. 197, pp. 1095-1100, Jul. 2015.

[16] S. Jinap, A. Ilya-Nur, S. Tang, P. Hajeb, K. Shahrim, and M. Khairunnisak, 'Sensory attributes of dishes containing shrimp paste with different concentrations of glutamate and 5'nucleotides', Appetite, vol. 55, no. 2, pp. 238-244, 2010. 